\title{
Jatropha curcas latex inhibits the release of collagenase by gingival fibroblast
}

\author{
Fazwishni Siregar ${ }^{1}$, S.M. Soerono Akbar ${ }^{2}$
}

\begin{abstract}
Folkloric use of J. curcas latex among others are to cure tooth pain, bleeding gum and as anti-inflammatory drug. Collagenase is a neutral protease released by activated macrophage and also by fibroblasts in small amounts. The aim of this study was to evaluate the effect of J. curcas latex on collagenase released by fibroblasts. Four doses of J. curcas latex from 37.5-300 $\mu \mathrm{g} / \mathrm{ml}$ were added to 3 human gingival primary fibroblast cell culture. After 1 to 4 days of incubation, collagenase in the supernatant was assayed with collagen. The degradation products were then separated by SDS-PAGE and the density of 3/4 $\alpha A$ bands were measured semi quantitatively by Adobe Photo computer program. Result showed that J. curcas latex decreased collagenase released by human gingival fibroblast, and increasing dose inhibits more. It may be concluded that the latex of J. curcas inhibits the release of collagenase by human gingival fibroblast. (Med J Indones 2007; 16:219-23)
\end{abstract}

\begin{abstract}
Abstrak
Penggunaan tradisional getah jarak (J. curcas) antara lain untuk mengobati sakit gigi, gusi berdarah, dan anti-inflamasi. Kolagenase adalah protease netral yang dihasilkan oleh sel makrofag dan juga sel fibroblast yang diaktivasi. Tujuan penelitian adalah mengetahui efek getah jarak terhadap pelepasan kolagenase oleh sel fibroblast. Tiga kultur sel fibroblast primer dari gingiva manusia yang telah dikultur sampai konfluen, kemudian ditambahkan 4 dosis getah jarak dan IL-1 $\beta$ untuk aktivasi. Setelah diinkubasi selama 1 sampai 4 hari, cairan supernatan diambil dan diukur kadar kolagenase dengan esei enzimatik menggunakan substrat kolagen. Hasil degradasi dipisah dengan SDS-PAGE. Kepadatan pita 3/4 aA yang merupakan pita khas hasil degradasi kolagen oleh kolagenase diukur secara semikuantitatif dengan program komputer Adobe Photo. Hasil menunjukkan bahwa. getah jarak menurunkan pembebasan kolagenase oleh fibroblas dan makin tinggi konsentrasi getah jarak, makin besar penghambatan. Dapat disimpulkan bahwa getah jarak menghambat pelepasan kolagenase oleh fibroblast gingiva manusia. (Med J Indones 2007; 16:219-23)
\end{abstract}

Keywords: Jatropha curcas, collagenase, human gingival fibroblast, collagenase assay, SDS-PAGE

Jatropha curcas, Euphorbiaceae, is a shrub or tree found in tropical areas. J. curcas latex contains tannins, saponins, wax, and resin. ${ }^{1}$ Phytochemical screening by Ciulei method identified the main chemical compounds in J. curcas latex which were sterols, flavone aglycones in the ether extract, tannins, reducing compounds, sterol glycosides in the ethyl acetate extract, and tannins, reducing compounds, poliose, saponins in the aqueous extract. ${ }^{2}$ A proteolytic enzyme called curcain can be obtained from the latex by alcohol and acetone precipitation. Curcain is a phytotoxin, which is a toxic protein molecule. ${ }^{3,4}$

In tropical Africa and Southeast Asia the latex is used as hemostatic and a wound dressing and is said to be

\footnotetext{
Graduate from Doctorate Program, Faculty of Dentistry, University of Indonesia, Jakarta, Indonesia

2 Faculty of Dentistry, University of Indonesia, Jakarta, Indonesia
}

efficacious in treating scabies, eczema, and ringworm. The latex is applied topically to wasp and bee stings. Furthermore, it is used as a mouth rinse to treat bleeding gums and to soothe a baby's inflamed tongue. In Indonesia and the Philippines, a little latex on absorbent cotton is commonly used to cure toothache. ${ }^{1,5,6}$ The latex is used as anti-inflammatory by massaging the latex on the traumatic area. ${ }^{7}$

Collagenase is a protease secreted by macrophage, neutrophyl, and also by activated fibroblast. ${ }^{8-11}$ It has the unique ability to degrade collagen generating $3 / 4$ $\alpha \mathrm{A}$ fragment, which is characteristic to collagen degraded by collagenase. ${ }^{12}$ This enzyme is important in connective tissue remodeling occurring in normal processes or wound healing, for degradation and resolution of inflammation, however, in certain disease it may result in articular destruction. If collagenase is secreted into extra cellular tissues, it may degrade collagen, basal membrane, and other tissues components. 
Collagen products by collagenase degradation are chemotactic to macrophage, and macrophage accumulation will happen and inflammation will increase. In articular disease it may bring an extensive damage. ${ }^{9}$ Enzyme secretion can be induced by several agents as endotoxin, immune complex, and IL-1 $\beta .{ }^{8}$ In periodontal disease, collagenase increase with the severity of the disease. ${ }^{13}$

Several methods are known to detect collagenase products among others is collagenase activity assay with collagen as substrate which products are then separated by sodium dodecyl sulphate polyacrylamide electrophoresis (SDS-PAGE) ${ }^{8,10}$ The purpose of this study was to evaluate the effect of Jatropha curcas latex on the release of collagenase by fibroblast cells.

\section{METHODS}

Materials used for cell culture were: Dulbecco's modified Eagle medium (DMEM), bovine serum albumin (BSA), penicillin G and gentamycin sulphate (Sigma), fetal bovine serum (FBS, Gibco), IL-1 $\beta$. Three gingival fibroblast primary cell cultures were donated from the lab of Cell Biology and Histology, Amsterdam Medical Center.

Latex of J. curcas was obtained from trees grown in Research Institute for Plant Medicine and Spices, Bogor, The latex was lyophilized 50 hours and stored at $-20^{\circ} \mathrm{C}$. Fresh latex was equivalent with $15 \%$ solution of freeze-dried latex.

Materials for collagenase assay: APMA buffer: $7 \mathrm{mg}$ APMA (4-aminophenyl mercuric acetate) was weighed in a glass test tube. Then $100 \mu \mathrm{l} 1 \mathrm{~N} \mathrm{NaOH}$ solution and $1000 \mu \mathrm{l}$ distilled water was added and shaked vigorously. About $10 \mu \mathrm{l} 2 \mathrm{~N} \mathrm{NaOH}$ solution was added and shaked well, followed by $900 \mu \mathrm{l}$ distilled water addition. To make APMA buffer, $1 \mathrm{ml}$ APMA solution was added to $9 \mathrm{ml}$ collagenase buffer (according to Ohshima). ${ }^{8}$ Collagenase assay buffer: Tris $50 \mathrm{mM} \mathrm{pH}$ 7.5, $\mathrm{CaCl}_{2} 10 \mathrm{mM}, \mathrm{NaCl} 150 \mathrm{mM}$. Collagen (ICN).

Materials for SDS-PAGE: acrylamide 30\% (Biorad), sodium dodecyl sulphate (SDS), Tris, ammonium persulfat (Biorad), TEMED (Biorad), mercaptoethanol, bromophenol blue (BPB), glycerol. SDS 20\%: $200 \mathrm{~g}$ SDS and $800 \mathrm{ml}$ deionized water was heated to $68^{\circ} \mathrm{C}$, and $\mathrm{pH}$ was adjust to 7.2 with $\mathrm{HCl}$. Solution was stored at room temperature. $1.5 \mathrm{M}$ Tris $\mathrm{HCl} \mathrm{pH} \mathrm{8.8:}$ $18.171 \mathrm{~g}$ Tris was dissolved in $100 \mathrm{ml}$ distilled water and $\mathrm{pH}$ was adjusted to 8.8 with $\mathrm{HCl}$, and was stored at room temperature. $1 \mathrm{M}$ Tris $\mathrm{HCl} \mathrm{pH}$ 6.8: $12.114 \mathrm{~g}$ Tris was dissolved in $100 \mathrm{ml}$ distilled water and $\mathrm{pH}$ was adjusted to 6.8 with $\mathrm{HCl}$ and was stored at room temperature. Tris glycine electrophoresis buffer, stock 5X: $15.1 \mathrm{~g}$ or $25 \mathrm{mM}$ Tris base, $94 \mathrm{~g}$ or $250 \mathrm{mM}$ glycine, were dissolved in $900 \mathrm{ml}$ deionized water. Then, $50 \mathrm{ml} 10 \%$ SDS was added and $\mathrm{pH}$ was adjusted to 8.3. Distilled water was added until the volume of $1.000 \mathrm{ml}$ was reached and was stored at room temperature. Before used, it was diluted 5 times with deionized water. Ammonium persulfat (APS) stock $10 \% \mathrm{w} / \mathrm{v}: 1 \mathrm{~g}$ APS, $10 \mathrm{ml}$ deionized water, and then was aliquot to $0.3 \mathrm{ml}$, and freeze. SDS loading buffer 1X: $50 \mathrm{ml} 100 \mathrm{mM}$ Tris $\mathrm{HCl}, \mathrm{pH} 6.8$, mercaptoethanol, $2 \%$ SDS, $0.1 \%$ bromophenol blue, $10 \%$ glycerol, stored at $-20^{\circ} \mathrm{C}$. Coomassie Brilliant Blue (CBB): $0.25 \mathrm{~g}$ CBB R250, $45 \mathrm{ml}$ methanol, 45 $\mathrm{ml}$ distilled water, $10 \mathrm{ml}$ glacial acetic acid, filtered with Whatman no 1 filter paper. Destaining: 30\% methanol, $10 \%$ acetic acid, $60 \%$ distilled water. $8 \%$ resolving gel: $4.6 \mathrm{ml}$ distilled water, $2.7 \mathrm{ml} 30 \%$ acrylamide, $22.5 \mathrm{ml} 1.5 \mathrm{M}$ Tris $\mathrm{pH} 8.8,0.1 \mathrm{ml}$ ammonium persulfat, $0.006 \mathrm{ml}$ TEMED. Stacking gel 5\%: $3.4 \mathrm{ml}$ distilled water, $0.83 \mathrm{ml} \mathrm{30 \%}$ acrylamide, $0.63 \mathrm{ml} 1.0 \mathrm{M}$ Tris pH 6.8, $0.05 \mathrm{ml} 10 \%$ SDS, $0.05 \mathrm{ml}$ ammonium persulfat, $0.005 \mathrm{ml}$ TEMED.

\section{Procedure}

Human gingival fibroblast primary cells were cultured with DMEM-FBS $10 \%$ in 6-well plates. At confluency, the medium was changed with DMEM-BSA 0.1\% added by 4 concentrations of latex from $37.5-300$ $\mu \mathrm{g} / \mathrm{ml}$, and $10 \mathrm{ng} / \mathrm{ml} \mathrm{IL-1 \beta}$ to activate collagenase production. Following 1 to 4 days of incubation, supernatants were taken and stored at $-20^{0} \mathrm{C}$. Twentymicrolitre sample was incubated in collagenase assay buffer with APMA to activate latent collagenase at $37^{0} \mathrm{C}$ for 30 minutes. Enzyme assay was carried out by adding $10 \mu \mathrm{l}$ collagen $(2.8 \mu \mathrm{g} / \mathrm{ml})$ and incubated overnight at $22^{\circ} \mathrm{C}$. Enzyme reaction was stopped by adding SDS loading buffer and heating for 5 minutes at $95^{\circ} \mathrm{C}$. Reaction products were separated by SDSPAGE. After overnight CBB staining, the gel was destained for 30 minutes. The gel with blue bands was then photographed, copied into computer disc, and the $3 / 4 \alpha \mathrm{A}$ bands density were measured semiquantitatively by Adobe Photo computer programme. Evaluation was based on comparing the density of $3 / 4 \alpha \mathrm{A}$, which is characteristic of collagen degraded by collagenase. 


\section{RESULTS}

\begin{tabular}{|c|c|c|c|c|c|c|c|c|c|c|c|c|c|c|}
\hline Lane & 1 & 2 & 3 & 4 & 5 & 6 & 7 & 8 & 9 & 10 & 11 & 12 & 13 & 14 \\
\hline Collagen & + & + & + & + & + & + & + & + & + & + & + & + & + & - \\
\hline Supernat & - & S1 & S1 & $\mathrm{S} 1$ & S1 & S1 & $\mathrm{S} 1$ & S2 & S2 & $\mathrm{S} 2$ & $\mathrm{~S} 2$ & $\mathrm{~S} 2$ & S2 & MWM \\
\hline IL-1 $\beta$ & - & + & + & + & + & - & + & + & + & + & + & + & - & - \\
\hline $\mathrm{Jc} \mu \mathrm{g} / \mathrm{ml}$ & - & - & 37 & 75 & 150 & - & 300 & - & 37 & 75 & 150 & 300 & - & - \\
\hline
\end{tabular}

Lane 14, molecular weight marker (MWM). Arrow, 3/4 $\alpha \mathrm{A}$ band. Longer culture time produced more collagenase. Increasing latex decreased collagenase released.

Figure 1. SDS-PAGE gel of collagenase assay with collagen substrat. Sample was supernatant (S) of gingival fibroblast cell culture given J. curcas (Jc) for 1 day (S1) and 2 days (S2).

\begin{tabular}{|c|c|c|c|c|c|c|c|c|c|c|c|c|c|c|}
\hline Lane & 1 & 2 & 3 & 4 & 5 & 6 & 7 & 8 & 9 & 10 & 11 & 12 & 13 & 14 \\
\hline Collagen & + & + & + & + & + & + & + & + & + & + & + & + & + & + \\
\hline Supernat & - & S3 & S3 & S3 & S3 & $\mathrm{S} 3$ & S3 & S4 & S4 & S4 & $\mathrm{S} 4$ & S4 & DME & S4 \\
\hline IL-1 $\beta$ & - & + & + & + & + & - & + & + & + & + & + & - & - & + \\
\hline $\mathrm{Jc} \mu \mathrm{g} / \mathrm{ml}$ & - & - & 37 & 75 & 150 & - & 300 & - & 37 & 75 & 150 & - & - & 300 \\
\hline
\end{tabular}

Lane 13, medium DMEM-BSA 0,1\%. Arrow, $3 / 4 \alpha$ A band. Longer culture time produced more collagenase. Increasing latex decreased collagenase released.

Figure 2. SDS-PAGE gel of collagenase assay with collagen substrat. Sample was supernatant (S) of gingival fibroblast cell culture given J. curcas $(J c)$ for 3 days (S3) and 4 days (S4).

Table 1. Semiquantitative measurement of $3 / 4 \alpha \mathrm{A}$ band from day 1 and 2

\begin{tabular}{lcc}
\hline J. curcas & Day 1 & Day 2 \\
\hline None & 103 & 100 \\
$0 \mu \mathrm{g} / \mathrm{ml}$ & 77 & 127 \\
$37,5 \mu \mathrm{g} / \mathrm{ml}$ & 60 & 94 \\
$75 \mu \mathrm{g} / \mathrm{ml}$ & 41 & 39 \\
$150 \mu \mathrm{g} / \mathrm{ml}$ & 22 & 2 \\
$300 \mu \mathrm{g} / \mathrm{ml}$ & 22 & 0 \\
\hline
\end{tabular}

Band measurement by Adobe Photo program. At Table 1, the standard 0 was collagen without supernatan of cell culture (Fig. 1 lane 1), standard 100 was collagen with supernatan of day 2 (Fig. 1 lane 13). Increasing latex decreased the density of $3 / 4 \alpha \mathrm{A}$ band.

Table 2. Semiquantitative measurement of $3 / 4 \alpha \mathrm{A}$ band from day 3 and 4

\begin{tabular}{lcc}
\hline J. curcas & Day 3 & Day 4 \\
\hline None & 99 & 90 \\
$0 \mu \mathrm{g} / \mathrm{ml}$ & 83 & 111 \\
$37,5 \mu \mathrm{g} / \mathrm{ml}$ & 73 & 100 \\
$75 \mu \mathrm{g} / \mathrm{ml}$ & 51 & 70 \\
$150 \mu \mathrm{g} / \mathrm{ml}$ & 16 & 14 \\
$300 \mu \mathrm{g} / \mathrm{ml}$ & 7 & 0 \\
\hline
\end{tabular}

At Table 2, the standard 0 was collagen without supernatan of cell culture (Fig. 2 lane 1), standard 100 was collagen with supernatan activated by IL- $1 \beta$ and latex $J$. curcas $37,5 \mu \mathrm{g} / \mathrm{ml}$ of day 4 (Fig. 1 lane 13). Increasing latex decreased the density of $3 / 4 \alpha \mathrm{A}$ band.

Longer culture time released more collagenase proved by the increasing density or thicker $\alpha \mathrm{A}$ bands in control cells from day 1 (Fig.1, lane 6), day 2 (Fig.1, lane 13), day 3 (Fig. 2, lane 6), and thickest at day 4 (Fig. 2, lane 12). The $\alpha \mathrm{A}$ bands from the IL-1 $\beta$ activated groups were also increased from day 1 (Fig. 1, lane 2) and thicker on day 4 (Fig. 2, lane 8). Collagenase was also released in sample not activated by IL- $1 \beta$ that were appeared as $\alpha$ A band at lane 6 Fig. 1 .

Addition of increasing dose of J. curcas latex narrowed the bands that were no longer observed at $300 \mu \mathrm{g} / \mathrm{ml}$ latex. At lane 7 and 14 Fig. 2 treated with $37.5 \mu \mathrm{g} / \mathrm{ml}$ latex, the $3 / 4 \alpha \mathrm{A}$ bands were appeared clearly. These bands narrowed at lane 4 and 10 Fig. 2 which treated with $75 \mu \mathrm{g} / \mathrm{ml}$ latex and more narrowed if treated with $150 \mu \mathrm{g} / \mathrm{ml}$ latex as appeared at lane 5 and 11 Fig. 2.

Semiquantitative measurement of $3 / 4 \alpha \mathrm{A}$ band (Table 1) on Figure 1 also showed that increasing dose of J. curcas 
latex decreased the density of $3 / 4 \alpha \mathrm{A}$ band from 77 on day 1 and 127 on day 2 at $0 \mu \mathrm{g} / \mathrm{ml}$ to 22 on day 1 and 0 on day 2 at concentration $300 \mu \mathrm{g} / \mathrm{ml}$ latex. Similar result was observed on semiquantitative measurement Table 2 taken from Figure 2. The density of $3 / 4 \alpha A$ bands were decreased from 83 at $0 \mu \mathrm{l} / \mathrm{ml}$ to 7 at $300 \mu \mathrm{l} / \mathrm{ml}$ on day 3 and from 111 at $0 \mu \mathrm{l} / \mathrm{ml}$ to 0 at $300 \mu \mathrm{l} / \mathrm{ml}$ on day 4.

The result showed that $J$. curcas latex inhibits the release of collagenase, and increasing dose inhibits more.

\section{DISCUSSION}

The purpose of this study was to investigate the effect of latex on the collagenase release by human fibroblast. Collagenase is release mainly by activated macrophage, but it can also be produced and released by activated fibroblast though in small amount. ${ }^{8}$ In this study, collagenase was also released in sample not activated by IL-1 $\beta$ that were appeared as $3 / 4 \alpha \mathrm{A}$ band at lane 6 Fig. 1. For control was supernatant of cell culture that neither added with latex nor activated by IL-1.

The narrowing of bands observed in the addition of $\mathrm{J}$. curcas latex was interpreted as inhibition of collagenase released. These narrowing bands were already seen in very low latex concentration $(37,5 \mu \mathrm{l} / \mathrm{ml})$ and at 300 $\mu \mathrm{g} / \mathrm{ml}$ no more bands were seen. Preliminary study showed that this latex did not eliminate collagenase activity. Addition of increasing dose of J. curcas latex lowered the band density observed at Table 1 and 2 .

The inhibition of collagenase release is probably because of the cytotoxic effect of the latex that influenced the productivity of cells. In this study, the latex concentration was not that killed all the cells, but those that reduced the cells into nearly half compared to the control. This was acquired from cytotoxicity study with MTT assay. ${ }^{14}$

In tissues, it is possible that absorption of latex in small amount may inhibit collagenase production. This enzyme production inhibition may decrease the severity of inflammation. In Peru, the latex is used as anti-inflammatory by massaging in traumatic area. ${ }^{7}$ In South East Asia the latex is used to cure toothache. ${ }^{6}$ It is also used as gargle in bleeding gum ${ }^{5}$ that may be interpreted as gingival inflammation or marginal periodontitis. Beside its tannin content, its hemostatic and cytotoxic activity, it is also possible that the inhibition of collagenase release, which increases in inflammation, take place. Inhibition of collagenase release will consequently reduce its effects in tissues.

From this study, it may be concluded that J. curcas latex inhibits the release of collagenase by human gingival fibroblast primary cell culture.

\section{Acknowledgement}

This study was funded in part by DAAD, Institut für Physiologische Chemie J. Gutenberg Mainz Germany, Cell Biology and Histology Amsterdam Medical Center Amsterdam Netherlands, URGE Batch III Indonesia, and J. Freisleben.

\section{REFERENCE}

1. Perry LM, Metzger J. Medicinal Plants of East and Southeast Asia. Cambridge: MIT Press; 1980. p. 246-7.

2. Siregar F, Soerono Akbar SM, Chairul. Phytochemical screening and hemolytic activity of Jatropha curcas L. (Euphorbiaceae) latex. Proceeding international seminar on natural product chemistry and utilization of natural resources. Depok, Indonesia. 2001.

3. Nath LK, Dutta SK. Extraction and purification of curcain, a protease from the latex of Jatropha curcas Linn. Indian J Pharmacol. 1991. 43(2): 111-4.

4. Nath LK, Dutta SK. A kinetic study on curcain, a protease from the latex of Jatropha curcas Linn. Indian J Pharmaceut. Sci 1989. 51; 43-7.

5. Heyne K. Tumbuhan Berguna Indonesia (Useful plants of Indonesia), Vol II. 1st Ed. Jakarta: Translated by Litbang Kehutanan. 1987. p. 1180-2.

6. Suwondo S. Improving the use of the Indonesian traditional herbal medicine for the prevention of caries and gingivitis on the basis of antibacterial activity test against streptococcus mutans and clinical trial on gingivitis [Dissertation]. Bandung: Padjadjaran Univ. 1993.

7. de Feo V. Uso di planti ad azione antiinflammatoria nell'Alto Ucayall, Peru Orientale. Fitoterapia 1989. 62: 481-94.

8. Ohshima M, Otsuka K, Suzuki K. Interleukin-1 $\beta$ stimulates collagenase production by cultured human periodontal ligament fibroblasts. J Periodontal Res 1994. 29: 421-9.

9. Sigal LH, Ron Y. Immunology and inflammation. Basic mechanism and clinical consequences. New York: McGraw-Hill Inc. 1994. p. 186-91, 328-33, 366-70, 381-2.

10. Sorsa T, Ding YL, Ingman T, Sallo T, Westerlund U, Haapasalo M, Tschesche H, Konttinen YT. Cellular source, activation and inhibition of dental plaque collagenase. J. Clin. Periodontol 1995. 22: 709-17.

11. Tuter G, Serdar MA, Yalim M, Gurhan IS, Balos K. Evaluation of matrix metalloproteinase-1 and tissue inhibitor of metalloproteinase-1 levels in gingival fibroblast of cyclosporin A-treated patients. J Periodon 2002. 73: 1273-8. 
12. Balbin M, Fueyo A, Knauper V, Pendas AM, Lopez JM, Jimenez MG, Murphy G, Lopez-Otin C. Collagenase 2 (MMP-8) expression in murine tissue remodeling processes. J Biol Chem 1998. 273: 23959-68.

13. Pozo P, Valenzuela MA, Melej C, Zaldivar M, Puente J, Martinez B, Gamonal J. Longitudinal analysis of metalloproteinases, tissue inhibitors of metalloproteinases and clinical parameters in gingival crevicular fluid from periodontitis-affected patients. J Periodont Res 2005. 40: 199-7.

14. Siregar F, Akbar SMS. Cytotoxicity of Jatropha curcas (Euphorbiaceae) latex on fibroblast by MTT assay. Med J Indones 2000. 9: 253-257. 